\title{
When is the Appropriate Time for Superficial Corneal Metallic Foreign Body Removal?
}

\section{Kornea Yüzeyindeki Metalik Yabancı Cisimleri Çıkarmanın En Uygun Zamanı Nedir?}

\author{
๑ Abdullah Aşur ${ }^{1}$, ๑ Onur Gökmen² \\ ${ }^{1}$ University of Health Sciences Turkey, Van Training and Research Hospital, Clinic of Ophthalmology, Van, Turkey \\ ${ }^{2}$ Yüzüncü Yıl University Faculty of Medicine, Department of Ophthalmology, Van, Turkey
}

Background: This study aims to compare the differences of corneal epithelial defects after the removal of foreign body (FB) according to clinic arrival dates.

Materials and Methods: Patients with metallic FB removed from the corneal surface were examined and divided into three groups according to their clinic arrival dates. The diameter of the FB was measured before removal, and the width and length of the epithelial defect were measured, and the area of the defect was calculated and compared between the groups.

Results: In this prospective study, totally 110 patients with metallic FB burrs in the cornea were examined. There were 54 patients in the first arrival day group, 34 patients in the second day group and 22 patients were in the third day and after arrival group. The FB diameter was $0.97 \pm 0.5 \mathrm{~mm}$ in the first day group, and the mean area of the epithelial defect after removal was $3.59 \pm 2.3 \mathrm{~mm}^{2}$. In the second group, FB diameter was $1.05 \pm 0.4 \mathrm{~mm}$, and the epithelial defect was $3.16 \pm 1.6 \mathrm{~mm}^{2}$, and in the third group, FB diameter and epithelial defect was respectively $1.01 \pm 0.41 \mathrm{~mm}$ and $1.68 \pm 1.5 \mathrm{~mm}^{2}$, and less iatrogenic epithelial defects were observed in the patients who had FB removed after the third day compared to the $1^{\text {st }}$ and the $2^{\text {nd }}$ groups. $(p=0.002, p=0.050$, respectively).

Conclusion: It may be more beneficial to remove the FB after epithelial regeneration and cup formation, by waiting 1-2 days under topical antibiotic prophylaxis rather than increasing the iatrogenic corneal damage by trying to scrape the rust ring under panic and stress.

Keywords: Metallic foreign body, eye trauma, rust ring, cornea, epithelial defect

Amaç: Bu çalışma, korneal yabancı cisim (YC) çıkarıldıktan sonra oluşan epitel defektlerinin, hastaların kliniğe varış sürelerine göre karşılaştırmasını amaçlamaktadır.

Gereç ve Yöntemler: Kornea yüzeyinden metalik YC çıkarılan hastalar muayene edildi ve kliniğe geliş tarihlerine göre üç gruba ayrıldı.YC'nin çapı çıkarılmadan önce ölçüldü ve epitel defektinin genişliği ve uzunluğu değerlendirildi, defektin alanı hesaplandı ve gruplar arasında kıyaslandı.

Bulgular: Bu prospektif çalışmada, korneada metalik YC olan toplam 110 hasta incelendi. İlk gün gelen 54 hasta, ikinci gün 34

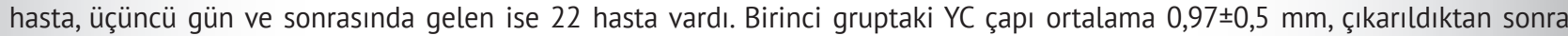

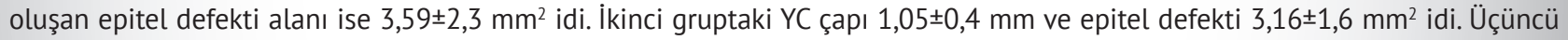

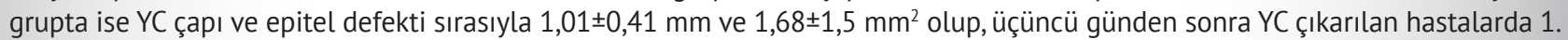
gruba ve 2. gruba göre daha az iyatrojenik epitel defekti görülmüştür (sırasıyla p=0,002, p=0,050).

Sonuç: Panik ve stres altında pas halkasını kazımaya çalışarak iyatrojenik kornea hasarını artırmaktansa, epitel rejenerasyonu ve cup formasyonundan sonra, topikal antibiyotik profilaksisi altında 1-2 gün bekleyerek YC'nin çıkarılması daha faydalı olabilir. Anahtar Kelimeler: Metalik yabancı cisim, göz travması, pas halkası, kornea, epitel defekti

Address for Correspondence: Onur Gökmen, Yüzüncü YII University Faculty of Medicine, Department of Ophthalmology, Van, Turkey Phone: +90 5074670767 E-mail: onurgkmen@gmail.com ORCID ID: orcid.org/0000-0002-6058-4226 


\section{Introduction}

The damage caused by foreign body (FB) on the corneal surface is the most common and preventable eye trauma in the eye. Metallic FB is the most common of these FBs (1). Patients usually present to the outpatient clinic on the day of the trauma because of pain due to trauma to the cornea. In the classical approach, the FB is removed immediately, the existing corneal rust is cleaned, antibiotic and lubrication drops are given, and corneal wound healing of the affected eye is provided, and it is called to control by keeping it closed until this healing is completed $(2,3)$. However, some patients reach the polyclinic days after the occurrence of trauma, and in these patients, corneal button formation and rust ring formation can be seen and wound healing takes a different course (4). In this study, we aimed to compare the differences between epithelial defects occurring between the immediate removal of the FB and the removal of the FB after days in the eye injury due to corneal metallic FB.

\section{Material and Methods}

In this prospective study, patients admitted to the eye clinic of University of Health Sciences Turkey, Van Training and Research Hospital between 2016 and 2018 due to metal burr trauma in the cornea were included. Patients were divided into three groups, the first group consisted of patients whose metallic body was removed on the first day of trauma, the second group consisted of patients whose FB was removed on the second day of trauma, and the third group consisted of patients whose FB was removed on the third day and after trauma. FB was removed on the same day in all patients admitted to the outpatient clinic. Patients with previous corneal trauma, recurrent epithelial defects, corneal degeneration or dystrophy, with previous keratitis corneal scar, and previous ocular surgery were excluded from the study. Patients under 18 years of age and over 50 years of age were excluded from the study.

The study was approved by the Local Ethics Committee (date: 21.07.2016-number: 2016/7). The research was adhered to the tenets of the Declaration of Helsinki, and detailed written informed consent was obtained before each individual's participation in the study.

All the patients were Turkish Caucasians. First, demographic data of the participants, including age and sex, were obtained. Thereafter, anterior segment examination was performed with a biomicroscope to the patients and the FB diameter was measured with the light of a slit lamb microscope and noted with other examination findings. Then, for topical anesthesia Alcaine $^{\circledR}$ (0.5\% proparacaine) drop was instilled into the eyes of the patients. The corneal metallic FB was scraped out of the cornea by the same physician at the head of the biomicroscope with minimal trauma to the stroma and epithelium with the help of 23 gauge insulin syringe tip (AA). After FB removal, the eyes of all patients were closed for 24 hours with tobramycin ophthalmic pomade, thereafter lubricant drops and ofloxacin antibiotic drops were used 4 times a day for 5 days.

After that, corneal epithelial defects were stained with fluorescein coated strips (Haag Streit ${ }^{\circledR}$ ) and the width and length of the defect were again measured by slit lamb light of the biomicroscope and the area of the defect was calculated as the multiplication of the width and length of this defect.

\section{Statistical Analysis}

Statistical analyses were performed using SPSS version 20.0 for Windows (SPSS, Inc, Chicago, IL). Normality analyses of variables were checked by the Kolmogorov-Smirnov and Shapiro-Wilk tests. Numerical variables were shown as mean-standard deviation or median (minimum-maximum). Categorical variables were expressed as frequency and percentage. ANOVA test was used to evaluate statistical differences, and post-hoc Tukey test was performed between the groups. Values of $p<0.05$ were considered statistically significant.

\section{Results}

In this prospective study, 110 patients with corneal metallic FB burrs were examined. FB in the cornea of 54 patients was removed on the first day of trauma, it was removed on the second day in 34 patients, 22 patients were admitted to the outpatient clinic after the third day after the trauma and FB was removed, and they were included in the study and grouped.

Of the 54 patients in the first group, 52 (96.3\%) were male and 2 (3.7\%) were female; in the second group, 33 (97.1\%) were male and $1(2.9 \%)$ was female; all of (100\%) the third group were male. The mean ( \pm standard deviation) age of the participants was $30.9 \pm 6.5$ years in the first group, and $29.35 \pm 5.1$ and $30.0 \pm 5.5$ years in the second group and third group, respectively. No significant differences were observed among the study groups with respect to age and sex $(p=0.470$, and $p=0.640$ respectively). No keratitis, corneal abscess formation or corneal scar formation was observed in any of the patients with FB removal. While rust ring formation was present in 45 (83\%) patients in the first group, rust ring developed in all patients in the second and third groups.

The FB diameter, width, length and size of the epithelial defect after the removal of the FB in each group are shown in Table 1. The comparisons among the groups are shown in Table 2.

\section{Discussion}

Corneal abrasions and corneal FB have an incidence of approximately $0.2-0.3 \%$ and constitute the majority of eye patients presenting to the emergency department. They frequently 
Table 1. Mean values of groups

\begin{tabular}{|c|c|c|c|c|c|c|c|}
\hline \multicolumn{2}{|l|}{ Groups } & Patient number & Minimum & Maximum & Range & Mean & \pm SD \\
\hline \multirow{4}{*}{ First day clinic arrival } & Foreign body diameter (mm) & 54 & 0.50 & 2.50 & 2.00 & 0.97 & \pm 0.5 \\
\hline & Defect width (mm) & 54 & 0.50 & 3.50 & 3.00 & 1.77 & \pm 0.6 \\
\hline & Age (years) & 54 & 21.00 & 45.00 & 24.00 & 30.9 & \pm 6.5 \\
\hline & Defect size $\left(\mathrm{mm}^{2}\right)$ & 54 & 0.75 & 10.50 & 9.75 & 3.59 & \pm 2.3 \\
\hline & Defect width (mm) & 34 & 1.00 & 2.75 & 1.75 & 1.76 & \pm 0.4 \\
\hline $\begin{array}{l}\text { Secona day cuinic } \\
\text { arrival }\end{array}$ & Defect height (mm) & 34 & 0.75 & 3.00 & 2.25 & 1.72 & \pm 0.5 \\
\hline & Age (years) & 34 & 20.00 & 43.00 & 23.00 & 29.35 & \pm 5.1 \\
\hline & Defect size $\left(\mathrm{mm}^{2}\right)$ & 34 & 1.13 & 7.5 & 6.38 & 3.16 & \pm 1.6 \\
\hline & Age (years) & 22 & 22.00 & 37.00 & 15.00 & 30.0 & \pm 5.5 \\
\hline & Defect size $\left(\mathrm{mm}^{2}\right)$ & 22 & 0.75 & 5.63 & 4.88 & 1.68 & \pm 1.5 \\
\hline & SD: Standard deviation & & & & & & \\
\hline
\end{tabular}

Table 2. Comparison of groups according to foreign body diameter, defect width, defect height and defect size

\begin{tabular}{|c|c|c|}
\hline \multicolumn{2}{|l|}{ Post hoc Tukey tests } & \multirow[b]{2}{*}{$p$} \\
\hline & Mean difference & \\
\hline \multicolumn{3}{|l|}{ Foreign body diameter } \\
\hline $\begin{array}{l}\text { Group } 1 \text { vs Group } 2 \\
\text { Group } 1 \text { vs Group } 3 \\
\text { Group } 2 \text { vs Group } 3 \\
\text { Defect width }\end{array}$ & $\begin{array}{r}-0.08388 \\
-0.04377 \\
0.04011\end{array}$ & $\begin{array}{l}0.705 \\
0.931 \\
0.905\end{array}$ \\
\hline $\begin{array}{l}\text { Group } 1 \text { vs Group } 2 \\
\text { Group } 1 \text { vs Group } 3 \\
\text { Group } 2 \text { vs Group } 3 \\
\text { Defect height }\end{array}$ & $\begin{array}{l}0.00844 \\
0.47769^{*} \\
0.46925^{*}\end{array}$ & $\begin{array}{l}0.997 \\
0.003^{*} \\
0.007^{*}\end{array}$ \\
\hline $\begin{array}{l}\text { Group } 1 \text { vs Group } 2 \\
\text { Group } 1 \text { vs Group } 3 \\
\text { Group } 2 \text { vs Group } 3 \\
\text { Defect size }\end{array}$ & $\begin{array}{l}0.1266 \\
0.64268^{*} \\
0.51604^{*}\end{array}$ & $\begin{array}{l}0.598 \\
0.001^{*} \\
0.006^{*}\end{array}$ \\
\hline $\begin{array}{l}\text { Group } 1 \text { vs Group } 2 \\
\text { Group } 1 \text { vs Group } 3 \\
\text { Group } 2 \text { vs Group } 3\end{array}$ & $\begin{array}{l}0.50708 \\
1.90614^{*} \\
1.39906^{*}\end{array}$ & $\begin{array}{l}0.535 \\
0.002^{*} \\
0.050^{*}\end{array}$ \\
\hline
\end{tabular}

present to the emergency department with the complaints of red-eye, photophobia, watery eyes, and blepharospasm (5). The FB seen on the cornea is removed from the cornea with a routine approach. Prophylactic, antibiotic, lubrication or therapeutic contact lenses are applied to the patients and followed-up. This approach is practiced by almost all emergency physicians and ophthalmologists in routine practice $(2,6)$. But, are superficial metallic corneal FBs really an ophthalmic emergency? When is the appropriate time for corneal FB removal? When we see a FB in the cornea, do we really treat the patient by scraping from the cornea under emergency conditions, or do we cause a lot more iatrogenic damage to the cornea? To our knowledge, there are very few studies in the literature that can satisfactorily answer the above questions. In this study, we aimed to find answers to the above questions by evaluating the iatrogenic epithelial defect that occurs after the removal of FB in the cornea and the times when the FB was removed. FB was removed on the first day of trauma in 54 out of 110 patients and the mean epithelial defect was $3.59 \pm 2.3 \mathrm{~mm}^{2}$. Epithelial defect was found to be $3.16 \pm 1.6$ $\mathrm{mm}^{2}$ in 34 patients in the second group. The mean epithelial defect was found to be $1.68 \pm 1.5 \mathrm{~mm}^{2}$ in 22 patients in the third group and removed after the third day. In the patients whose FB was removed after the third day, less iatrogenic epithelial defects were found to be statistically significant than the first and second groups. $(p=0.002, p=0.050$ respectively).

There is a possibility of infectious keratitis and corneal scar formation due to FB on the surface of the cornea, but infectious keratitis is more likely to develop due to organic FB damage. The risk of infectious keratitis due to inorganic objects such as metal, plastic and stone is very low. As a matter of fact, cases of stone fragments that can remain asymptomatic in the eye for 60 years without any medical treatment (7), as well as cases of contact lenses that remain uninfected with topical antibiotic drops on the cornea for 7 years, have been reported (8). In a study on 100 people performed by Ramaknishnan et al. (9) with superficial corneal metallic bodies, only 1 (1\%) patient admitted on the first 
day developed infectious keratitis and was treated with topical antibiotic drops. Another risk may be siderosis bulbi, the earliest occurrence being reported after 18 days for an intraocular metallic body. It can be predicted that this risk will be much lower in the metallic FB on the corneal surface (10). The metallic object is exposed to high temperatures during hammering or after welding. This may have a sterilizing effect on the body and reduce the risk of developing keratitis, but this hypothesis needs to be supported by further studies. Another problem that may occur when the FB waits on the cornea is the formation of rust ring. The rust ring is formed by the diffusion and oxidation of the iron deposits around the metallic object $(4,11)$. Another formation to be followed here is the formation of rust ring around the FB in the $1^{\text {st }}$ hour after the trauma and formation of a cup with a white ring developing around the rust ring from the $1^{\text {st }}$ day (Figure 1). The white ring around the rust ring contains white cells and is responsible for corneal scar formation $(11,12)$. According to our observations in this study, this cup comes out more easily with the rust ring in patients coming after the $3^{\text {rd }}$ day (Figure $2,3)$. In corneal superficial iron $\mathrm{FB}$, immediate intervention to the patient within the first hour may be important in order to avoid scarring in the cornea because rust has not yet formed in this circuit. If this period has passed, the urgency of the case has disappeared since rust formation has started. At this stage, removing the FB may be against the patient, not in the favor of the patient because the patient is irritated and painful at this stage. By removing the blepharospasm due to these, the removal of the FB and the rust ring formed may be partially possible under difficult conditions. It may even result in the spread of rust and rust ring on the corneal surface. It may be in the best interest of the patient to wait for cup formation at this stage in the removal of the corneal superficial iron $\mathrm{FB}$, and then remove the $\mathrm{FB}$ in a much shorter time and with less iatrogenic damage to the cornea.

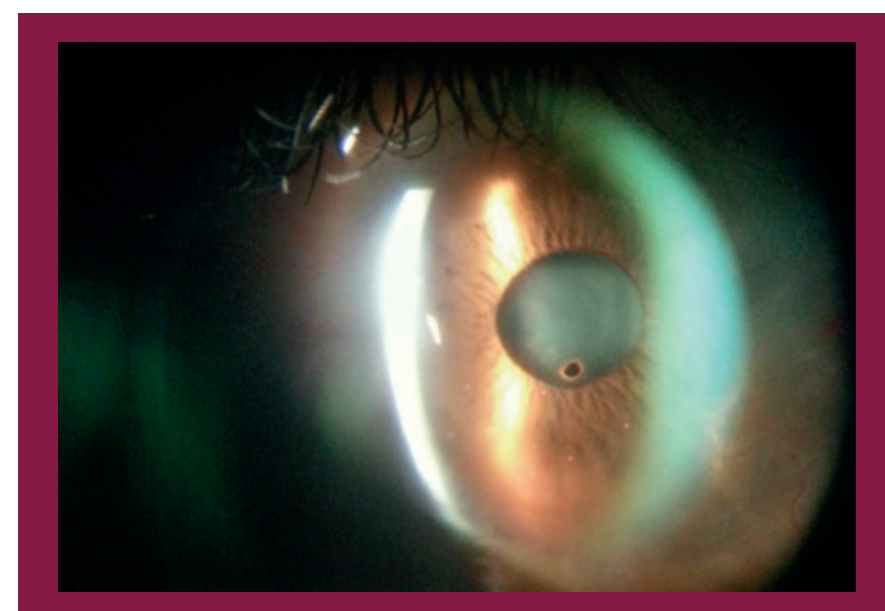

Figure 1. The rust ring around the FB in the middle and the white ring surrounding it and the cup starting from the first day FB: Foreign body

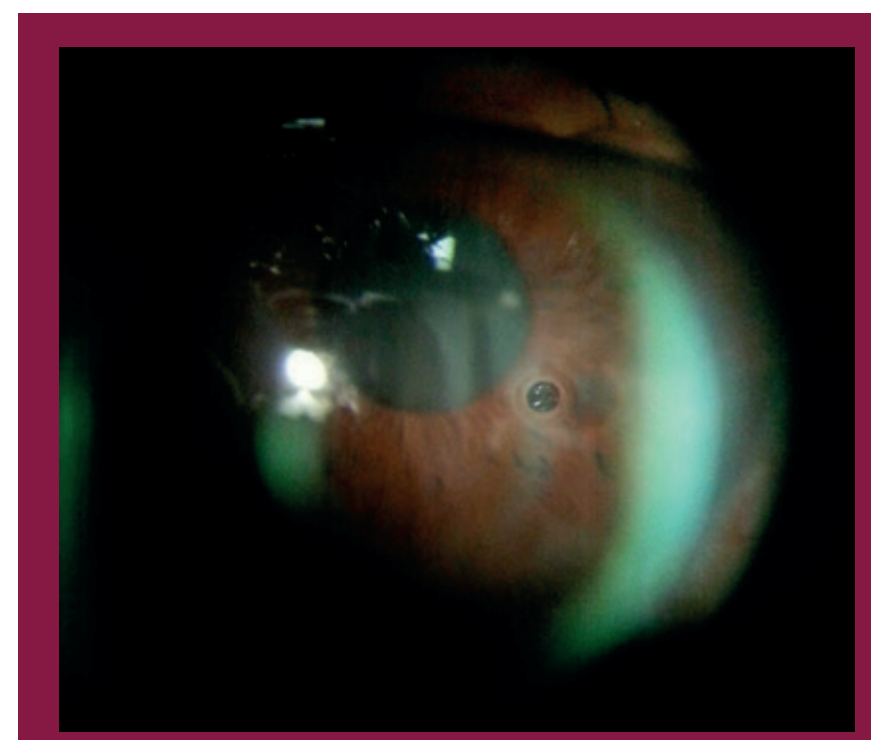

Figure 2. In another patient presenting after the seventh day, the $\mathrm{FB}$ in the middle, the transparent ring surrounding it and the outermost dirty white ring and the formation of the completed cup FB: Foreign body

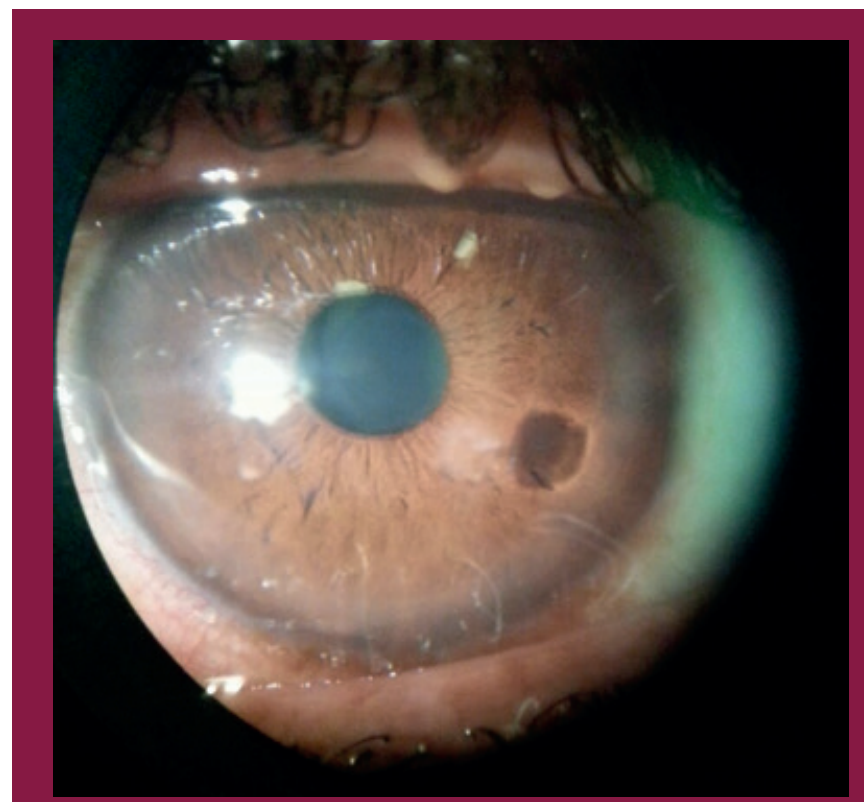

Figure 3. Same patient at Figure 2, after the removal of the FB and the cup. After the FB was easily removed, there was no rust or scar in the cornea. (The shadow of the corneal laceration on the iris appears on the right side of the lesion and after 24 hours the laceration is completely lost)

FB: Foreign body

\section{Conclusion}

If the metallic FB remains on the cornea for more than 1 hour, rust ring formation usually develops. Therefore, after the first hour, we think that the superficial metallic corneal FB is not an 
ophthalmic emergency. When we see the patient who is agitated with stress and panic after the formation of the rust ring, rather than attempting to remove the rust ring, we suggest that it may be more beneficial to remove $\mathrm{FB}$ with less iatrogenic damage by waiting 1-2 days under topical antibiotic prophylaxis and observing the formation of the cup. However, this hypothesis should be supported by further studies.

\section{Ethics}

Ethics Committee Approval: The study was approved by the Local Ethics Committee (date: 21.07.2016-number: 2016/7).

Informed Consent: Written informed consent was obtained before each individual's participation in the study.

Peer-review: Externally peer-reviewed.

\section{Authorship Contributions}

Surgical and Medical Practices: A.A., Concept: A.A., Design: A.A., Data Collection or Processing: A.A., Analysis or Interpretation: O.G., Literature Search: O.G., Writing: O.G., A.A.

Conflict of Interest: No conflict of interest was declared by the authors.

Financial Disclosure: The authors declared that this study received no financial support.

\section{References}

1. Gobba F, Dall'Olio E, Modenese A, De Maria M, Campi L, Cavallini GM. WorkRelated Eye Injuries: A Relevant Health Problem. Main Epidemiological
Data from a Highly-Industrialized Area of Northern Italy. Int J Environ Res Public Health. 2017;14:604. [Crossref]

2. Mutie D, Mwangi N. Managing eye injuries. Community Eye Health. 2015;28:48-49. [Crossref]

3. Patel D. Eye injuries: improving our practice. Community Eye Health 2015;28:41-43. [Crossref]

4. Dilly N. What is a rust ring? Cornea. 2012;31:1355-1357. [Crossref]

5. Ahmed F, House RJ, Feldman BH. Corneal Abrasions and Corneal Foreign Bodies. Prim Care. 2015;42:363-375. [Crossref]

6. Fraenkel A, Lee LR, Lee GA. Managing corneal foreign bodies in officebased general practice. Aust Fam Physician. 2017;46:89-93. [Crossref]

7. Gokmen O, Yesilirmak N, Kal A, Eroglu FC. Unusual presentation of an intraocular foreign body retained for sixty years. Cont Lens Anterior Eye. 2014;37:234-235. [Crossref]

8. Yesilirmak N,Altinors DD. A silicone hydrogel contact lens after 7 years of continuous wear. Cont Lens Anterior Eye. 2013;36:204-206. [Crossref]

9. Ramakrishnan T, Constantinou M, Jhanji V, Vajpayee RB. Corneal metallic foreign body injuries due to suboptimal ocular protection. Arch Environ Occup Health. 2012;67:48-50. [Crossref]

10. Loporchio D, Mukkamala L, Gorukanti K, Zarbin M, Langer P, Bhagat N. Intraocular foreign bodies: A review. Surv Ophthalmol. 2016;61:582-596. [Crossref]

11. Woodburn B. Rust ring removal. Can J Rural Med. 2014;19:35. [Crossref]

12. Mednick Z, Tabanfar R, Alexander A, Simpson S, Baxter S. Creation and validation of a simulator for corneal rust ring removal. Can J Ophthalmol. 2017;52:447-452. [Crossref] 